\title{
Characteristics of Sesame (Sesamum Indicum l.) Seed Meal Grown in the Northern Region of Bangladesh
}

\author{
Sarmina Yeasmin ${ }^{1 *}$, Tahmina Akter Chowdhury ${ }^{1}$, GM Masud Rana ${ }^{1}$, Md Mahmudur Rahman ${ }^{1}$ \\ and Lailatul Ferdousi ${ }^{2}$ \\ ${ }^{1}$ Oils, Fats and Waxes Research Division, Bangladesh Council of Scientific and Industrial Research (BCSIR), Bangladesh \\ ${ }^{2}$ Applied Zoology Research Division, Bangladesh Council of Scientific and Industrial Research (BCSIR), Bangladesh \\ *Corresponding author: Sarmina Yeasmin, Oils, Fats and Waxes Research Division, Bangladesh Council of Scientific and Industrial \\ Research (BCSIR), Bangladesh
}

\section{ARTICLE INFO}

Received: 慧 July 19, 2021

Published: 㴋 August 09, 2021

Citation: Sarmina Yeasmin, Tahmina Akter Chowdhury, GM Masud Rana, Md Mahmudur Rahman, Lailatul Ferdousi. Characteristics of Sesame (Sesamum Indicum l.) Seed Meal Grown in the Northern Region of Bangladesh. Biomed J Sci \& Tech Res 38(1)-2021. BJSTR. MS.ID.006083.

Keywords: Oil; Sesame Seed; Meal; Minerals; Protein; Aflatoxin; Fatty Acids; Phytochemicals

\begin{abstract}
Oil was extracted from sesame seed by hydraulic press and the physico-chemical characteristics such as moisture content, density, specific gravity, Refractive index, free fatty acid, acid value, iodine value, peroxide value and unsaponifiable matters were determined. Proximate analysis of defatted seed meal were done. The residual oil was extracted by organic solvents as the residual oil deteriorates and degrades the quality of seed meal during the storage. The carbohydrate content in defatted meal was found to be the highest $(56.7 \%)$ and protein was $22.5 \%$. The major minerals such as $\mathrm{Ca}, \mathrm{Mg}, \mathrm{Na}$ $\mathrm{K}, \mathrm{Fe}$ and $\mathrm{Zn}$ were estimated by AAS. It was found that almost all the mineral contents were higher except Fe $(2.9 \mathrm{mg} / 100 \mathrm{~g})$ and $\mathrm{Zn}(3.0 \mathrm{mg} / 100 \mathrm{~g})$. Presence of highly toxic and carcinogenic aflatoxin in seed meal was detected by applying ELISA (enzyme linked immunosorbent assay). Aflatoxin found in seed meal was very low, $0.113 \mathrm{ppb}$ than allowable limit ( $4 \mathrm{ppb}$ ) for human consumption. Fatty acids composition of the oil was determined by GCMS that revealed 6 fatty acids. Further, GC-MS study of the seed meal confirmed the presence of thirty bioactive compounds with glycerin $32.77 \%$ as predominant and maximum number of phytocompounds were observed.
\end{abstract}

\section{Introduction}

Sesame (Sesamum indicum L.) is an economically and nutritionally important crop and it is prized for oil. The global sesame market demand is rising with increasing health awareness. Sesame is one of the oldest oilseeds and is widely cultivated in both tropical and subtropical areas. Worldwide sesame seed consumption was USD 6559.0 million in 2018 and it will reach USD 7244.9 million by 2024, with a CAGR (compound annual growth rate) of $1.7 \%$ [1] In Bangladesh, sesame is an important summer oilseed crop occupying $9.4 \%$ of the total oilseed area [2]. Sesame is labeled as the queen of oilseeds because of its high oil content (35-45\%), delicious nutty aroma, and flavor [3] and a considerable amount of proteins, carbohydrates, essential minerals. Seeds contain high amount of methionine and tryptophan, fibers as well as secondary metabolites such as lignans, saponins, flavonoids, and phenolic compounds. Moreover, the seeds are a good source of calcium, phosphorus, iron, small amount of trace elements and are rich in vitamin B, E. Sesame oil has a pleasant, mild taste and is remarkably stable.

It has a high content of polyunsaturated fatty acids as oleic and linoleic acid. Sesame oil cake is good feed for poultry, fish, cattle, goat and sheep [4]. Oil cakes, the coarse residues after the removal of oil from various oilseeds is usually treated as waste products in Bangladesh. The average total production of oil cakes in Bangladesh is about 1,70,000 tons per annum [5]. Oil cakes are rich in protein and minerals, but their inherent values have never been considered actively. They are generally used as poultry and other animal feed or as fertilizer. Among the total production of oil cakes in Bangladesh, $70 \%$ of which are used as fertilizer, $10 \%$ is being 
exported and the remaining 15\% is available for animal feeding [6]. Sesame Oil cakes or defatted sesame meal can be an ideal source as a support matrix for various biotechnological processes for the production of enzymes, antibiotics, vitamins, antioxidants [7] and various food products. So, the sustainable utilization of this seed meal is necessary for preparing cattle, poultry and fish feed and also for the preparation of protein and vitamin enriched food stuff for men and poultry, fish farming.

The present work had therefore, been undertaken with a view to finding out the major constituents of the sesame seed oil and defatted seed meal so that the proper and effective utilization of these seed meal may be ensured.

\section{Materials and Methods}

Sesame seeds were purchased from katakhali bazar, Rajshahi, Bangladesh. Then the seeds were cleaned, dried and the oil was pressed out by hydraulic press. The meal thus obtained were freed from residual oil by solvent extraction. The residual oil was extracted in a Soxhlet apparatus with n-hexane. This solvent was selected as extraction solvent because it has better effect over other polar solvents like alcohol, ketone, aldehyde etc. [8]. Physical properties such as moisture content, refractive index, density, specific gravity and viscosity of the oil were determined by the method described by Garba, et al. [9] and AOAC [10]. Acid value, saponification value, iodine value, peroxide value, unsaponifiable matter and free fatty acid were estimated according to the AOAC [11].

The defatted seed meal were air dried, and analysis of nitrogen was carried out by Micro-Kjeldhal method, and the percentage of protein was calculated [12]. The defatted meal was also used for different analysis like ash [13], fiber [14], carbohydrate [15], residual fat [16] and moisture content [17]. The minerals such as calcium, potassium, phosphorous, magnesium, sodium and iron were determined by atomic absorption spectroscopy (Model: AA-68000, Shimadzu, Japan) coupled with an auto-sampler (ASC6100). The fatty acid composition of the sesame oil and the chemical compound of seed meal were analyzed by SHIMADZU GC-2010 was equipped with auto-sampler (AOC- 20s), auto-injector (AOC-20i) and SH Rxi 5MS Sill capillary column with $30 \mathrm{~m} \times 0.25 \mathrm{~mm} \times 0.25 \mu \mathrm{m}$ film. Detection of aflatoxin in seed meal is done following by the method Lee \& Rachmawati [18] (Figure 1).

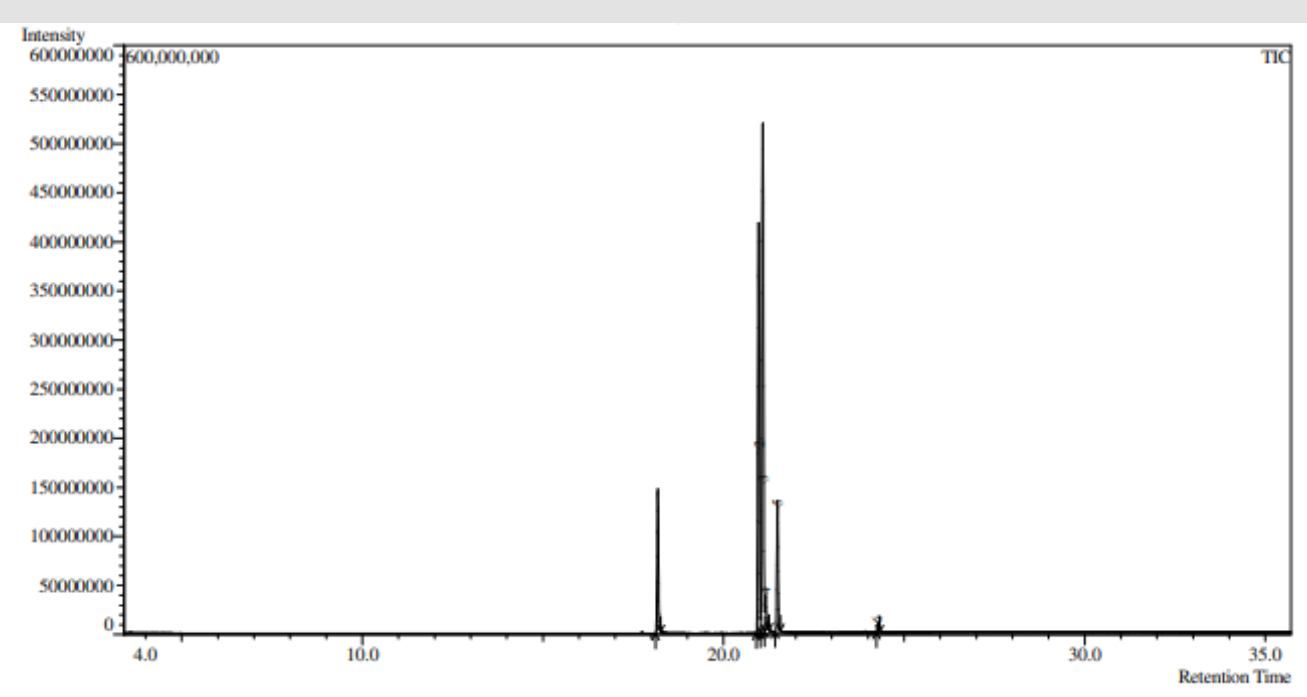

Figure 1: GCMS chromatogram of sesame oil.

\section{Results and Discussion}

Moisture, Density, specific gravity and refractive index of sesame oil were determined and depicted in Table 1 . All values were within the WHO/FAO permissible limits. The results showed in Table 1 that the free fatty acid, acid value, peroxide value, iodine value and unsaponifiable matters of oil were $0.40 \%, 0.81 \%, 3.96$ meq $\mathrm{O}_{2} / \mathrm{kg}, 118 \mathrm{~g} \mathrm{I}_{2} / 100 \mathrm{~g}$ and 2.1 respectively. These results were similar to those reported in other studies [19-21]. The proximate analysis of defatted sesame seed meal were determined, and the results were given in Table 2 . It was found that the protein content of meal was $22.5 \%$ and the carbohydrate content was the highest, $56.7 \%$. The content of crude fiber was $4.6 \%$ whereas moisture, ash and residual fat content were $5.5 \%, 6.8 \%$ and $3.9 \%$ respectively. All values were in an appreciable level. Table 3 showed the mineral contents of defatted sesame meal. Sesame meals contain good percentages of minerals which may added better nutritive value for foods or in pharmacological preparations. 
Table 1: Physicochemical characteristics of sesame oil.

\begin{tabular}{|c|c|}
\hline Properties & Sesame Oil \\
\hline Moisture content $(\%)$ & $0.03 \pm 0.01$ \\
\hline Density at $25^{\circ} \mathrm{C}$ & $0.8843 \pm 0.30$ \\
\hline Specific gravity at $25^{\circ} \mathrm{C}$ & $0.9019 \pm 0.05$ \\
\hline Refractive index at $25^{\circ} \mathrm{C}$ & $1.475 \pm 0.11$ \\
\hline Free Fatty Acid (as oleic $\%)$ & $0.40 \pm 0.14$ \\
\hline Peroxide value (meq o2/kg) & $3.96 \pm 0.33$ \\
\hline Iodine value $(\mathrm{g}$ I2 $/ 100 \mathrm{~g})$ & $118 \pm 0.45$ \\
\hline Acid value $(\%)$ & $0.81 \pm 0.02$ \\
\hline Unsaponifiable matter & $2.1 \pm 0.12$ \\
\hline
\end{tabular}

Table 2: Proximate composition of defatted sesame meal flour.

\begin{tabular}{|c|c|}
\hline Constituent & Amount in Percentage \\
\hline Moisture \% & $5.5 \pm 0.20$ \\
\hline Ash \% & $6.8 \pm 0.76$ \\
\hline Crude fiber \% & $4.6 \pm 0.51$ \\
\hline Residual fat \% & $3.9 \pm 0.22$ \\
\hline Protein \% & $22.5 \pm 0.93$ \\
\hline Carbohydrate \% & $56.7 \pm 0.52$ \\
\hline
\end{tabular}

Note: All the experiments were performed in triplicate and the results were expressed as mean $\pm \mathrm{SD}$ (standard deviation).

Scientists are looking for an alternate source of cheaper oil cake with low level of aflatoxin. The literature on the incidence of aflatoxin in sesame oil cake is scanty. Mirocha, et al. [22] reported the presence of Fusarium toxins in sesame seeds. While Laxma Reddy and Reddy [23] observed the incidence of trichothecene producing fungi was low as compared with that of Aspergillus and Penicillium species in sesame oil cake. The allowable limit of aflatoxin for human consumption is $4 \mathrm{ppb}$ [24]. Aflatoxin of seed meal was determined shown in Table 3 is 0.113 ppb that is much lower than allowable limit for human consumption. The fatty acid composition is an essential indicator of the nutritional value of the oil. Sesame seed oil belongs to the oleic-linoleic (mono unsaturation-poly unsaturation) acid group. It has $25 \%$ poly unsaturated fatty acid, 9,12-Octadecadienoic acid methyl ester and 31\% mono unsaturated fatty acid, 9-Octadecenoic acid methyl ester. Oil also consists of palmitic acid $22 \%$, stearic acids 19\% and Heneicosanoic acid, methyl ester 2.4\% (Table 4).The chemical compounds of sesame seeds were analyzed by GC-MS and summarized in Table 5 and their GC-MS chromatograph in Figure 2.

Table 3: Aflatoxin and some mineral contents in defatted sesame seed meal.

\begin{tabular}{|c|c|}
\hline Minerals & Amount $\mathbf{i n} \mathbf{~} \mathbf{~} / \mathbf{1 0 0 g}$ \\
\hline Sodium & $42.2 \pm 0.60$ \\
\hline Potassium & $120.3 \pm 0.29$ \\
\hline Calcium & $251.0 \pm 0.78$ \\
\hline Magnesium & $99.6 \pm 0.51$ \\
\hline Iron & $2.9 \pm 0.20$ \\
\hline Phosphorus & $198 \pm 0.73$ \\
\hline Zinc & $3.0 \pm 0.42$ \\
\hline
\end{tabular}

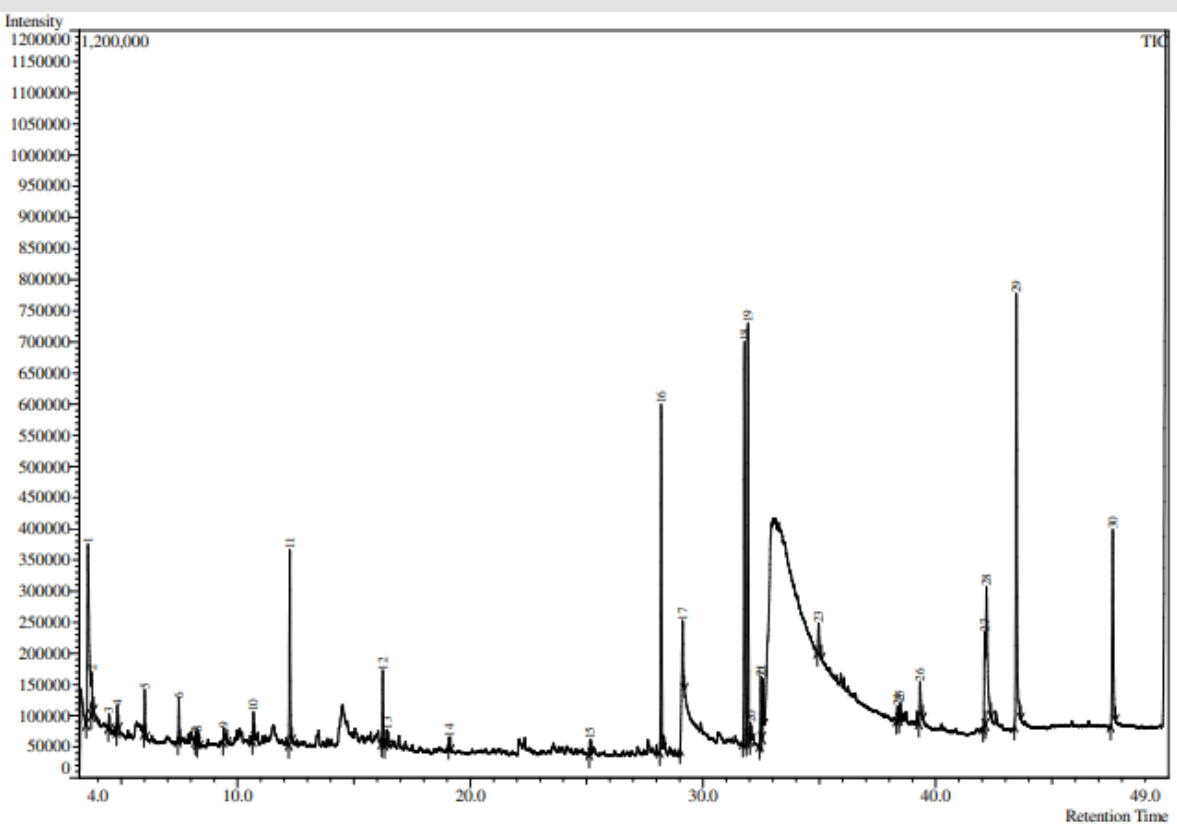

Figure 2: GCMS chromatogram of sesame seed meal. 
Table 4: Fatty acid composition of sesame oil.

\begin{tabular}{|c|c|c|c|c|}
\hline ID & Name & Retention Time & Area & Concentration \% \\
\hline 1 & Hexadecanoic acid, methyl ester (Palmitic acid) & 18.172 & 32580890 & 22.0604 \\
\hline 2 & 9,12-Octadecadienoic acid (Z, Z)-, methyl ester (Lenoleic acid) & 20.987 & 37109728 & 25.12685 \\
\hline 3 & 9-Octadecenoic acid, methyl ester, (E) (Oleic acid) & 21.103 & 37680438 & 25.51328 \\
\hline 4 & 9-Octadecenoic acid (Z)-, methyl ester (Oleic acid) & 21.166 & 8248245 & 5.58485 \\
\hline 5 & Octadecanoic acid, methyl ester (Stearic acid) & 21.495 & 28476534 & 19.28135 \\
\hline 6 & Heneicosanoic acid, methyl ester & 24.274 & 3593678 & 2.43327 \\
\hline
\end{tabular}

Table 5: Identification of the chemical compounds present in sesame seed meal.

\begin{tabular}{|c|c|c|c|c|}
\hline ID & Name & Retention Time & Area & Concentration \% \\
\hline 1 & Glycerin & 3.575 & 1270671 & 33.09018 \\
\hline 2 & 1-Butene, 4-isothiocyanato- & 3.732 & 23642 & 0.61567 \\
\hline 3 & 2-Propyl-1-pentanol, pentafluoropropionate & 4.481 & 11852 & 0.30864 \\
\hline 4 & Benzeneacetaldehyde & 4.835 & 51517 & 1.34158 \\
\hline 5 & Nonanal & 6.013 & 24670 & 0.64244 \\
\hline 6 & Isoborneol & 7.479 & 41553 & 1.0821 \\
\hline 7 & 3-Cyclohexene-1-methanol, .alpha.,.alpha.4-trimethyl- & 8.226 & 7028 & 0.18302 \\
\hline 8 & Estragole & 8.28 & 5499 & 0.1432 \\
\hline 9 & Benzaldehyde, 4-(1-methylethyl)- & 9.416 & 9963 & 0.25945 \\
\hline 10 & p-Cymen-7-ol & 10.679 & 39012 & 1.01593 \\
\hline 11 & Phenol, 2-methoxy-3-(2-propenyl)- & 12.249 & 121496 & 3.16394 \\
\hline 12 & Phenol, 3,5-bis(1,1-dimethylethyl)- & 16.243 & 105315 & 2.74256 \\
\hline 13 & 3-Allyl-6-methoxyphenol & 16.416 & 14004 & 0.36469 \\
\hline 14 & Hexadecane & 19.097 & 24514 & 0.63838 \\
\hline 15 & Heneicosane & 25.152 & 17725 & 0.46159 \\
\hline 16 & Hexadecanoic acid, methyl ester & 28.206 & 416891 & 10.85647 \\
\hline 17 & Eicosanoic acid & 29.127 & 113649 & 2.95959 \\
\hline 18 & 9,12-Octadecadienoic acid, methyl ester & 31.782 & 190150 & 4.95179 \\
\hline 19 & 9-Octadecenoic acid, methyl ester, (E)- & 31.934 & 170027 & 4.42776 \\
\hline 20 & 11-Octadecenoic acid, methyl ester & 32.049 & 7360 & 0.19167 \\
\hline 21 & Octadecanoic acid, methyl ester & 32.488 & 70596 & 1.83843 \\
\hline 22 & 2H-Pyran-2-one, tetrahydro-6-undecyl- & 32.578 & 42734 & 1.11286 \\
\hline 23 & $(+)$-Sesamin & 34.972 & 26040 & 0.67812 \\
\hline 24 & 3-Cyclopentylpropionic acid, 2-dimethylaminoethyl ester & 38.36 & 42243 & 1.10007 \\
\hline 25 & Fumaric acid, 2-dimethylaminoethyl nonyl ester & 38.458 & 68269 & 1.77783 \\
\hline 26 & Hexadecanoic acid, 2-hydroxy-1-(hydroxymethyl)ethyl ester & 39.325 & 27680 & 0.72083 \\
\hline 27 & 1,8,11-Heptadecatriene, (Z,Z)- & 42.107 & 55065 & 1.43398 \\
\hline 28 & 9-Octadecenoic acid, 1,2,3-propanetriyl ester, (E,E,E)- & 42.182 & 87926 & 2.28973 \\
\hline 29 & 13-Docosenamide, (Z)- & 43.465 & 314657 & 8.19414 \\
\hline 30 & gamma.-Tocopherol & 47.609 & 438276 & 11.41337 \\
\hline
\end{tabular}

GC-MS analysis of sesame seed meal identified 30 chemical compounds representing the highest yield, $32.77 \%$ of glycerin and 11.4\% gamma-tocopherol (vitamin E), 10.85\% hexadecanoic acid methyl ester and 8.19\% 13- docosenamide depending on relative area. Glycerin has antimicrobial and antiviral properties. Gammatocopherol is the main component and represented about $90.5 \%$ of total tocopherols, shows a higher antioxidant capacity as compared to alpha-tocopherol. Sesame oil rich in tocopherols and in lignans (notably sesamin and sesamolin) provide exceptional oxidative stability compared with other edible oils [25]. Hexadecenoic acid, methyl ester possesses antioxidant and anti-fungal property [26] and the presence of 13-Docosonamide impart antioxidant activity 
[27]. It was also found that there were some compounds in lower concentration including Phenol, 2-methoxy-3-(2-propenyl)-,3-Allyl6-methoxyphenol, 2-Propyl-1-pentanol, pentafluoropropionate that have antimicrobial activity [28].

Compound found in meal Phenol, 3,5-bis(1,1-dimethylethyl)is a naturally synthesized compound within both plant and bacterial cell that impart antioxidant [29], antibacterial [30] and antifungal activity [31]. Seed meal also contain 11-Octadecanoic acid methyl ester, Fumaric acid, 2-dimethylaminoethyl nonyl ester, Octadecanoic acid, methyl ester, Sesamin as well as many other bioactive compounds with relatively low concentration presented in Table 5. Rahman, et al. [32] reported that 11-octadecenoic acid methyl ester is responsible for antioxidant and antimicrobial activity. Fumaric acid, 2-dimethylaminoethyl nonyl ester has antimicrobial properties and Octadecanoic acid, methyl ester has anti-inflammatory properties. Sesamin, a major lignin isolated from sesame seeds and sesame oil, is known to possess antioxidant and anti-inflammatory properties, play a major role in a variety of cardiovascular diseases and biochemical actions [33].

\section{Conclusion}

Sesame is a valuable seed oil have numerous beneficial properties for applications in food industry. The present investigation indicates that it is a rich source of many essential nutrients that have beneficial and very positive effect on human health. The presence of good percentages of minerals, protein, carbohydrate and various essential bioactive compounds as well as other desirable fatty acids make the sesame seed suitable ingredient in the food and poultry industries.

\section{Acknowledgement}

The authors express their gratitude to Director, BCSIR Laboratories, Rajshahi for providing necessary laboratory facilities.

\section{References}

1. Global Sesame Seeds Market-Segmented by Geography-Growth, Trends, and Forescast (2020-2025). Mordor Intelligence.

2. BBS (2012) Agricultural Statistics of Bangladesh, Bangladesh Bureau of Statistics, Ministry of Planning, Dhaka, Bangladesh.

3. Johnson LA, Suleiman TM, Lusas EW (1979) Sesame Protein: A Review and Prospectus. J Am Oil Chem Soc 56(3): 463-468.

4. Khan MAH, Sultan NA, Islam MN, Hasanuzzaman M (2009) Yield and yield contributing characters of sesame as affected by different management practices. American-Eurasian Journal of Scientific Research 4(3): 195197.

5. Rahman MS, Hasan M, Ali MH, Hossain MA, Uddin MM (2005) Comparative Studies on the Major Constituents of Some Oil Cakes in Bangladesh. Bangladesh J Sci Ind Res 40(3-4): 261-266.

6. Huq MS, Rubbi SF (1980) Effect of Processing's of Oil Cakes and Their Residual Oils. Bangladesh J Sci Ind Res 15(1-4): 89.

7. Ramachandran S, Singh SK, Larroche C, Soccol CR, Pandey A (2007) Oil cakes and their biotechnological applications. A review. Bioresource Technology 98(10): 2000-2009.
8. Horn RJ, Koltun SrSP, Graci AV (1982) Jr. JAOCS 59: 647A.

9. Garba AA, Medugu DW, Gwaski PA, Amusat RO (2015) Extraction and characterization of moringa oleifera seed oil. Applied Research Journal 1(9): 473-477.

10. (1995) AOAC. Official methods of analysis ( $16^{\text {th }}$ Edn.)., Washington, DC: Association of Official Analytical Chemists.

11. (1999) AOAC International. Official Methods of Analysis of AOAC International, (16 ${ }^{\text {th }}$ Edn.)., Gaithersburg.

12. (1990) AOAC. Official method of analysis of the Association of Official Analytical Chemist. AOAC International, Arlington (USA), No 934.06.

13. (2002) ASTM. Standard Test Method for Ash in pulp, paper and paper product (D586-97). American Society for Test Material, Philadelphia PA, USA.

14. (1980) AOAC. Official method of analysis (ed. W. Horwitz). Association of Official Analytical Chemists (AOAC). (13 ${ }^{\text {th }}$ Edn.)., Washington D.C, pp. 1018.

15. Anon (1955) Official and tentative Methods of Analysis of the Association of Official and Agricultural Chemists, ( $8^{\text {th }}$ Edn.)., Washington, pp. 340470 .

16. Folch J, Lees M, Sloanestanley GH (1957) A simple method for the isolation and purification of total lipids from animal tissues. Journal of Biological Chemistry 226: 497-509.

17. (1971) ICOMR. A Manual of Laboratory Techniques Indian Council for Medical Research National Institute of Nutrition. India, p. 2-6.

18. Lee NA, Rachmawati S (2006) A rapid ELISA for screening aflatoxin B1 in animal feed and feed ingredients in Indonesia. Food and Agricultural Immunology 17(2): 1-14.

19. Wrostald RE, Decker EA, Schwartz SJ, Sporns P (2005) Handbook of food analytical chemistry: water, proteins, enzymes, lipids and carbohydrates. New Jersey: Wiley and Sons, Inc.

20. (2015) Codex Standards. Codex Standards for Edible Fats and Oils Not Covered by Individual Standards. Codex Stan 19-1981.

21. Tan HC, Ghazali MH, Kuntom A, Tan PC, Ariffin AA (2009) Extraction and physicochemical properties of low free fatty acid crude palm oil. Food Chemistry 113(2): 645-650.

22. Mirocha CJ, Pathre SV, Schauerhamer B, Christensen CM (1976) Applied and Environmental Biology, 32: 4. Quoted by R. Gordon Hemingway, J. Scott Inglis, Andrew Waterston, 1997. The Proceedings of the Nutrition Society 56: 306 A (Abstract).

23. Laxma Reddy, Reddy SM (1994) Incidence of trichothecene mycotoxin producing fungi in oil seed cakes. Indian J Anim Nutr 11: 101-106.

24. (2004) FAO. Worldwide regulations for mycotoxins in food and feed in 2003. FAO Food and Nutrition Paper 81, Rome, Food and Agriculture Organization of the United Nations.

25. Sun Hwang L (2005) Sesame oil. In: Fereidoon Shahidi (Edt.)., Bailey's Industrial Oil and Fat Products, Sixth Edition, Six Volume Set, John Wiley \& Sons.

26. Pinto Maria EA, Sthéfane Araújo G, Marcela Morais I, Nívea Sá P, Caroline Lima M, et al. (2017) Antifungal and Antioxidant Activity of Fatty Acid Methyl Esters from Vegetable Oils.|| Anais Da Academia Brasileira de Ciencias 89(3): 1671-1681.

27. Kumaradevan G, Damodaran R, Mani P, Dineshkumar G, Jayaseelan T (2015) Phytochemical Screening and GC-MS Analysis of Bioactive Components of Ethanol Leaves Extract of Clerodendrum Phlomidis (L.). American Journal of Biological and Pharmaceutical Research 2: 142-48.

28. Saravanan P, Chandramohan G, Mariajancyrani J, Shanmugasundaram $P$ (2014) GC-MS Analysis of Phytochemical Constituents in Ethanolic Bark Extract of Ficus Religiosa Linn. International Journal of Pharmacy and Pharmaceutical Sciences 6(1): 457-460. 
29. Choi Y, Lee J (2009) Antioxidant and Antiproliferative Properties of a Tocotrienol-Rich Fraction from Grape Seeds. Food Chemistry 114(4) 1386-1390.

30. Abdullah, Al shwyeh H, Mohamed E, Saeed M, Parveen J (2011) Antibacterial Activity of Malaysian Mango Kernel. African Journal of Biotechnology 10(81): 18739-18748.

31. Zhou BL, Chen ZX, Du L, Xie YH, Zhang Q et al. (2011) Allelopathy of Root Exudates from Different Resistant Eggplants to Verticillium Dahliae and the Identification of Allelochemicals. African Journal of Biotechnology 10(42): 8284-8290.

\section{ISSN: 2574-1241}

DOI: 10.26717/BJSTR.2021.38.006083

Sarmina Yeasmin. Biomed J Sci \& Tech Res

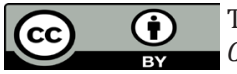

This work is licensed under Creative Commons Attribution 4.0 License

Submission Link: https://biomedres.us/submit-manuscript.php
32. Rahman MM, Ahmad SH, Mohamed MTM, Ab Rahman MZ (2014) Antimicrobial Compounds from Leaf Extracts of Jatropha Curcas, Psidium Guajava, and Andrographis Paniculata. The Scientific World Journal 2014: 635240.

33. Dalibalta S, Amin F Majdalawieh, Herak Manjikian, S Dalibalta (2020) Health benefits of sesamin on cardiovascular disease and its associated risk factors. Saudi Pharmaceutical Journal 28(10): 1276-1289.

$\begin{array}{ll}\text { BIOMEDICAL } & \text { Assets of Publishing with us } \\ \text { RESEARCHES } & \text { - Global archiving of articles } \\ \text { - Immediate, unrestricted online access } & \text { - Rigorous Peer Review Process } \\ & \text { - Authors Retain Copyrights } \\ & \end{array}$

